\title{
Efficacy of Aqueous Plant Extracts and Pesticide Against Okra Fruit Borer in Commercial Okra Cultivars
}

\section{Zafrullah Khan $^{1 *}$, Shah Alam Khan ${ }^{1}$, Naeem Khan ${ }^{2}$ and Noor Muhammad ${ }^{1}$}

${ }^{1}$ Department of Plant Protection, The University of Agriculture Peshawar, Pakistan

${ }^{2}$ Department of Weed Science, The University of Agriculture Peshawar, Pakistan

*Corresponding Author: Zafrullah Khan, Department of Plant Protection, The University of Agriculture Peshawar, Pakistan.

Received: October 25, 2019; Published: November 28, 2019

DOI: $10.31080 /$ ASAG.2019.03.0728

\begin{abstract}
The purpose of this study was to measure the effect of chemicals against Okra fruit borer. The use of chemicals against Okra fruit borer was studied in Nuclear Institute for Food and Agriculture (NIFA) Tarnab, Peshawar 2009. The plots were randomly selected for treatments. The chemicals used against Okra fruit borer were Nucleo Polyhydrosis virus (NPV), Peskil and Neem Seed Water Extract (NSWE). Among these Nucleo Polyhydrosis Virus (NPV) showed highly significant results against Okra fruit borer followed by Peskil and NSWE. It can be concluded that Nucleo Polyhydrosis Virus (NPV), Peskil and aqueous extracts of NSWE all have shown synergetic effect along the resistant Okra cultivars against Okra fruit borer and greatly increase the Okra yield parameters. Application of Nucleo Polyhydrosis Virus (NPV), Peskil and aqueous extracts of NSWE alongside sowing resistant Okra cultivars would give a more effective management of Okra fruit borer and higher yields of Okra fruit.
\end{abstract}

Keywords: Okra; Borer; NPV; Peskil; Neem Seed; Chemicals

\section{Introduction}

Okra (Hibiscus esculentus L.) Commonly known as bhindi or lady's finger belong to family Malvaceae. This genus of okra contains more than 140 species [1,2]. In Pakistan okra is grown in summer the area under cultivation is 232.05 hectares with the production of 303.16 tons per year [3]. Okra as a human food contains protein, vitamins, carbohydrate, fat, calcium, potassium and other mineral matters which are often lacking in the diet of developing countries. The okra fruits are useful with some medicinal values. A mucilaginous preparation from the pod can be used for plasma replacement or blood volume expansion. The okra fruit has good iodine contents which are useful to reduce goiter [4]. The ripened and mature pod seeds are used as chicken feed and also for oil production on small scale [5].

Okra production is affected by many biotic and abiotic factors, which cause significant yield losses. In biotic the insect pest especially the okra fruit borer (Earias vittella) is a major threat that reduces almost $50-70 \%$ yield [6,7]. In abiotic factors this may be due to the sowing time which significantly affect the population of the pest. Okra fruit borer cause substantial infestation depends on weather conditions (Kumar and Urs 1998). The pest are susceptible to relative humidity and like the maximum temperature and rainfall.

To control the different insect pests of okra crop, the Pakistan farmers used a wide range of insecticides during the vegetable season. The excessive use of pesticides causes some serious problems to humans, environmental pollution, development of pest resis- tance and affects the non-target organisms. The safe and alternate methods are required to adopt for okra pest management such as resistant cultivars compared to excessive use of insecticides [8].

An alternative management approach for Okra fruit borer could be the so called plants based bio-pesticides which can be useful in many perspectives such as bio-pesticides are safe to the environment, risk free to crop injury and no harmful effects on people and animal health (Regnault-Roger and Philogène, 2008; RegnaultRoger., et al. 2012). Application of bio-pesticides showed promise for pest management in different crops overseas and brought significant reduction in yield losses in various crops (Nicholson, 2007; Sawadogo., et al. 2009; Rattan, 2010). Plant extracts of many plant species [e.g. Neem - Azadirachta indica A. Juss., garlic - Allium sativum L., tobacco - Nicotiana tabacum L., and ginger - Zingiber zerumbet (L.) Sm.] have shown promise as bio-pesticides for management of insect pests and diseases in agriculture (Khater, 2012; Showler, 2017).

The extractions of various plant parts such as Seeds, leaves and barks, etc have the insecticidal properties and being practiced in Africa and Asia for pest management. To use plant botanicals having different positive aspects such as insecticidal activity and minimum toxicity to mammalian, no insect pest resistance development reported, less hazardous effects to non-target organisms, no pest resurgence problem, no adverse effect on plant growth, negligible application risks, low cost and easy availability (Prakash., et al. 1990). However, okra fruit is used as fresh vegetables and harvested at a fixed time, it will be much better to have safer management strategy having no pesticides residues on crops and fruits [9]. 
Keeping in view the importance of okra fruit borer infestation and its chemical and botanical control, this study was conducted with the following objectives. To study the effect of different chemicals including Neem seed extractions against okra fruit borer Earias vittella in field conditions. To determine the effect of the different chemicals and botanicals on the yield of okra crop.

\section{Materials and Methods}

Investigations were conducted in 2009 (June-August) in the Nuclear Institute for Food and Agriculture (NIFA) farm of the Division of Entomology. The okra crop was raised in Randomized Block Design with four treatments replicated four times in 14 plot size. The total number of subplots were 16 . Chemicals with their technical name, trade name, and doze.

\begin{tabular}{|l|c|c|c|c|c|}
\hline S.NO & Treatment & $\begin{array}{c}\text { Technical } \\
\text { Name }\end{array}$ & $\begin{array}{c}\text { Trade } \\
\text { Name }\end{array}$ & Doze/ha & $\begin{array}{c}\text { Doze for } \\
\text { Experiment }\end{array}$ \\
\hline 1 & T1 & NPV & Elcar & $200 \mathrm{ml} / \mathrm{ha}$ & $1.2 \mathrm{ml}$ \\
\hline 2 & T2 & Peskil & $\begin{array}{c}\text { Garden } \\
\text { king }\end{array}$ & $625 \mathrm{ml} / \mathrm{ha}$ & $3.6 \mathrm{ml}$ \\
\hline 3 & T3 & NSWE & $\begin{array}{c}\text { Neem } \\
\text { Oil }\end{array}$ & $7500 \mathrm{~g} / \mathrm{ha}$ & 42 \\
\hline
\end{tabular}

Table 1

Solution preparation of NS MIE, NPV and Peskil. A solution of different concentration i.e. \% of NSWE $<$ NPV and peskil was prepared by the formula.

\section{Explanation of formula}

$\mathrm{C}_{1}=$ Weight of chemicals required for okra field

$\mathrm{V}_{1}=$ Volume of water required for one treatment or for four plots

$\mathrm{C}_{2}=$ Weight of chemicals required for hectare

$\mathrm{V}_{2}=$ Volume of water required for hectare

The data was collected out as follow:

The fruits were collected in a shopping bag from each plot. The infested one was separated from the sound one.

\section{Data analysis}

The collected data was analyzed by the M STAT-C computer package of the mean table and was separated by using LSD Test (Gomez Gomez) 1984 [10].

The weight of sound fruit was found out by the following formula.

Sound fruit weight $=$ total fruit weight - infested fruit weight

\section{Results}

The effect of different chemicals for the control of okra fruit borer (E-vittela) was carried out Nuclear institute for and Agriculture (NIFA) Tarnab Peshawar infield during the month of June to August 2009.

Total Weight: data regarding of total weight of okra fruit are presented in Table 2.

\begin{tabular}{|c|c|c|c|c|c|}
\hline \multicolumn{7}{|c|}{ The mean Table Time interval } \\
\hline \multirow{2}{*}{ Weeks } & \multicolumn{5}{|c|}{ Treatments } \\
\cline { 2 - 6 } & Control T1 & NPV T2 & PeskilT3 & NSWET 4 & Mean \\
\hline Week 1 & $90.00 \mathrm{c}$ & $742.50 \mathrm{a}$ & $675.00 \mathrm{a}$ & $542.50 \mathrm{a}$ & $512.50 \mathrm{a}$ \\
\hline Week 2 & $90.00 \mathrm{c}$ & $742.50 \mathrm{a}$ & $675.00 \mathrm{a}$ & $542.50 \mathrm{a}$ & $512.50 \mathrm{a}$ \\
\hline Week 3 & $700.00 \mathrm{a}$ & $1037.50 \mathrm{a}$ & $835.00 \mathrm{a}$ & $762.50 \mathrm{a}$ & $833.75 \mathrm{a}$ \\
\hline Week 4 & $427.50 \mathrm{~b}$ & $492.50 \mathrm{~b}$ & $470.00 \mathrm{~b}$ & $417.50 \mathrm{~b}$ & $451.88 \mathrm{~b}$ \\
\hline Week 5 & $240.00 \mathrm{c}$ & $435.00 \mathrm{c}$ & $338.75 \mathrm{c}$ & $353.75 \mathrm{~b}$ & $341.88 \mathrm{c}$ \\
\hline Week 6 & $432.50 \mathrm{~b}$ & $247.50 \mathrm{~b}$ & $382.50 \mathrm{~b}$ & $360.00 \mathrm{~b}$ & $355.63 \mathrm{c}$ \\
\hline Week 7 & $92.50 \mathrm{c}$ & $1.5 .00 \mathrm{c}$ & $113.75 \mathrm{a}$ & $95.00 \mathrm{a}$ & $101.56 \mathrm{c}$ \\
\hline Mean & $296.07 \mathrm{c}$ & $543.21 \mathrm{a}$ & $498.57 \mathrm{~b}$ & $439.11 \mathrm{~b}$ & \\
\hline
\end{tabular}

Treatment: LSDO 05, 73.3803

Weeks: LSD005, 97.07301

Table 2: The effect of different chemicals against okra fruit borer (E-vittela) at different time intervals (weeks), on the total fruit weight.

Statistical analysis of the data revealed that different chemicals against okra fruit borer at a different time interval (weeks.) significantly affected fruit weight.

The mean value of the data showed that highest total fruit weight (543.21 g) was produced in plots where NPV was sprayed followed by Peskil (498.57g), which was at par with NSW E sprayed. The minimum total weight (296.07g) was produced in control plots.

In case of weeks highest total weight was produced by week 3 , which was at par with week2 and week l. Lower total yield $(101.50 \mathrm{~g})$ in the mean was recorded by week 7 .

For interaction between chemicals and weeks maximum total fruit yield (1037.50g) l was noted by spraying NPV in week3 followed by Peskil (835g) in week 3. Minimum total fruit yield (90g) was recorded in week l.

The statistical analysis of the data showed that the highest total weight was recorded in NPV (1037) followed by the Peskil which is (835) and the lowest weight was recorded from NSW E (762)- NPV and Peskil was recorded more efficient against okra fruit borer $(E$ vittela).

Infested weight: Data regarding the infested weight of okra fruit are presented in Table.

The statistical analysis of the data showed that the highest infestation was recorded in control (35.82g). The chemicals showed a varying infestation level in which highest 10 . The infestation was recorded in NSW E (5.39g), followed by NPV (4.00g). Peskil was proved to be the most efficient against $E$. vittela which showed the lowest infestation weight i.e. $2.89 \mathrm{~g}$.

Sound weight: Data regarding the Sound weight of okra fruit are presented in Table 3. 


\begin{tabular}{|c|c|c|c|c|c|}
\hline \multicolumn{7}{|c|}{ The mean Table Time interval } \\
\hline \multirow{2}{*}{ Weeks } & \multicolumn{5}{|c|}{ Treatments } \\
\cline { 2 - 6 } & Control T1 & NPV T2 & PeskilT3 & NSWET 4 & Mean \\
\hline Week 1 & $25.75 \mathrm{~b}$ & 5.50 & $675.00 \mathrm{a}$ & $542.50 \mathrm{a}$ & $512.50 \mathrm{a}$ \\
\hline Week 2 & $25.75 \mathrm{~b}$ & 5.50 & $675.00 \mathrm{a}$ & $542.50 \mathrm{a}$ & $512.50 \mathrm{a}$ \\
\hline Week 3 & $162.50 \mathrm{~b}$ & 12.50 & $835.00 \mathrm{a}$ & $762.50 \mathrm{a}$ & $833.75 \mathrm{a}$ \\
\hline Week 4 & 8.75 & 0.00 & $470.00 \mathrm{~b}$ & $417.50 \mathrm{~b}$ & $451.88 \mathrm{~b}$ \\
\hline Week 5 & 14.25 & 0.00 & $338.75 \mathrm{c}$ & $353.75 \mathrm{~b}$ & $341.88 \mathrm{c}$ \\
\hline Week 6 & 11.25 & $4.50 \mathrm{~b}$ & $382.50 \mathrm{~b}$ & $360.00 \mathrm{~b}$ & $355.63 \mathrm{c}$ \\
\hline Week 7 & 2.50 & $0.00 \mathrm{c}$ & $113.75 \mathrm{a}$ & $95.00 \mathrm{a}$ & $101.56 \mathrm{c}$ \\
\hline Mean & $296.07 \mathrm{c}$ & $543.21 \mathrm{a}$ & $498.57 \mathrm{~b}$ & $439.11 \mathrm{~b}$ & \\
\hline \multicolumn{7}{|c}{ Treatment LSD } \\
0.05 \\
Weeks LSD \\
0.05 \\
\hline
\end{tabular}

Table 3: Sound Weight: The effect of different chemicals against okra fruit borer (E. vittela) at different time intervals (weeks), on the sound fruit weight.

\section{Discussion}

The use of different chemicals and insecticides were significantly affected by total fruit weight. Higher total fruit weight was produced by the chemical NPV, followed by Peskil, whereas minimum total fruit weight was recorded in control treatment.

In week 3 , the maximum total fruit weight was obtained followed by weeks 2 and 1, lower total fruit yield was noted in week 7 .

The enhance in yield due these chemicals might be due to timely control of okra fruit borer, due to which loss was managed and hence resulted in higher yield.

The results are in line with gunasekaran and tangomen [11], who reported that various chemicals especially NSWE for control of okra fruit borer significantly increases the yield of okra.

The study evaluated by Akpbekar., et al. [12] of the effect of certain neem products against okra fruit borer with due comparison with some synthetic insecticides. The results revealed that all insecticidal treatments significantly reduced the percent fruit borer infestation on okra, both on the number and weight basis as compared to the untreated control. The comparison of neem products with the control treatments was the best in reducing the infestation of okra fruit borer.

The results were obtained by Safder., et al. [13] by various chemicals for the control of okra fruit borer from which he noted that these chemicals were so beneficial for the improvement of okra yield.

At the end of the experiment it was found that the use or 3 chemicals which are NPV, Peskil and NSW E are observed that these are very important for the control of okra fruit borer (Earias vittela) and for the increasing of okra yield. So use of these chemicals showed best results for the control of okra fruit borer and yield enhancement [14-21].

\section{Conclusion and Recommendation}

The present study was conducted to observe the efficacy of NPV, Peskil, and NSWE against okra fruit borer in field condition nuclear institution for food and Agriculture (NIFA) Tarnab Peshawar.

The result shows that the used chemicals not only improved the yield of okra but strongly affect the attack of okra fruit borer. So from this experiment these chemicals are recommended for the contras of okra fruit borer in Peshawar valley.

\section{Summary}

The, purpose of this study was to measure the effect of chemicals against Okra fruit borer. The use of chemicals against Okra fruit borer was studied in Nuclear Institute for Food - and Agriculture (NIFA) Tarnab, Peshawar 2009. The plots were randomly selected for treatments. The chemicals used against Okra fruit borer were Nucleo Polyhydrosis virus (NPV), Peskil and Neem Seed Water Extract (NSWE). Among these Nucleo Polyhydrosis Virus (NPV) showed highly significant results against Okra fruit borer followed by Peskil and NSWE.

\section{Bibliography}

1. Bayer $\mathrm{C}$ and Kubitzki K. "The families and genera of vascular plants". In: Malvaceae, (Ed. K. Kubitzki) (2003): 225-311.

2. Naveed A., et al. "Generation means analysis of water stress tolerance in okra (Abelmoschus esculentus L.)". Pakistan Journal of Botany 41 (2009): 195-205.

3. Kashif SR., et al. "The response of okra (Hibiscus esculentus L.) to soil has given encapsulated calcium carbide". Pakistan Journal of Botany 40.1 (2008): 175-181.

4. Savello P., et al. "Nutrition composition of okra seed meals". Journal of Agricultural and Food Chemistry 28 (1980): 11631166.

5. Oyelade OJBIO. "Ade-Omowaye and V.F. Adeomi. Influence of variety on protein, fat contents and some physical characteristics of okra seeds". Journal of Food Engineering 57 (2003): 111-114.

6. Schmutterer, H., et al. "Properties and potential of natural pesticides from the neem tree, Azadirachta indica". Annual Review of Entomology 35.1 (1990): 271-297.

7. Mani M., et al. "Biological control of lepidopterous pests of horticultural crops in India-A review". Agricultural Reviews 26.1 (2005): 39.

8. Devi LL., et al. "Biorational management of shoot and fruit borer of okra (Earias vittella Fab) and their effect on insect predators". Journal of Ecology of Environment 33.3 (2015): 1052-1054. 
9. Dhaliwal GS (Eds.). Agricultural pests of South Asia and their Management (4thedition). Kalyani Publishers, Ludhiana-New Delhi-Noida (U.P) Hyderabad-Channai-Kolkata, India 498 (2004).

10. Gomez K-A and AA Gomez. Problem Data. "Statistical procedure for a riculture research". Jhon willy and Sons. (1984): 272-315.

11. Gunasekaran and Tongrnin. "Neem oil as a potential seed dresser for managing Homopterous sucking pests of Okra (Abelmoschus esculentus (L.) Moench)”. 79 (2006): 103-111.

12. Ambekar JS., et al. "Bioefficacy of certain neem products against okra fruit borer”. 25 (2000): 42-43.

13. Safdar Ali., et al. Management of Yellow Vein Mosaic Disease of Okra Through Pesticide/Bio-pesticide and Suitable Cultivars". 07 (2005): 145-147.

14. Acharya S., et al. "Efficacy of Insecticides against Okra Jassid, Amrasca biguttula Ishida". 10 (2002): 0971-3573.

15. Incalcaterra $G$ and $F$ Vetrano. "Effécts of Two Sowing Dates and Plastic Mulch on Okra Production". Ishs Acta Horticulturae 533: VIll International Symposium on Timing Field Production in Vegetable Crops (2002).

16. Mohamed M and A Mohamed. Studies on the control of insect pests in vegetables (okra, tomato, and onion) in Sudan with special reference to neem preparations. 19 (1997- 1999): 1416.

17. Naresh V., et al. "Relative toxicity of some insecticides against the larvae of okra shoot and fruit borer, Earias vittella Fab. (Noctuidae: Lepidoptera)". 35 (2005): 741-752.

18. Paras N., et al. "Persistence and dissipation of Readymix formulations of insecticides in/on okra fruits". Environmental Monitoring and Assessment 107 (2005): 173-179.

19. Sardana HR and Tewari GC. "Effect of diflubenzuron on okra shoot and fruit borer, Earias vittella Fabricius". 6 (1989): 6975.

20. Singh BK., et al. Efficacy of certain synthetic insecticides and two botanicals against the okra fruit and shoot borer, Earias vittella (Fabr). 87 (2003): 224- 229.

21. Suman G., et al. "Persistence of New Insecticides and Their Efficacy Against Insect Pests of Okra". Bulletin of Contamination and Toxicology 82.7 (2009): 243-247.

\section{Volume 3 Issue 12 December 2019}

(C) All rights are reserved by Zafrullah Khan., et al. 